Journal of English Language Teaching and Applied Linguistics

ISSN: 2707-756X

DOI: $10.32996 /$ jeltal

Journal Homepage: www.al-kindipublisher.com/index.php/jeltal

\title{
Discussion of "xia" in Chinese from Semantics Perspective: Suggestions for Vietnamese Learners
}

\author{
Phung, Pho Cuong \& (D) \\ Ho Chi Minh City University of Food Industry, Ho Chi Minh City, Vietnam \\ $\square$ Corresponding Author: Phung, Pho Cuong, E-mail: cuongpp@hufi.edu.vn
}

\section{ARTICLE INFORMATION}

Received: May 08, 2021

Accepted: June 11, 2021

Volume: 3

Issue: 6

DOI: $10.32996 /$ jeltal.2021.3.6.18

\section{KEYWORDS}

Vietnamese learners, Contrastive analysis, Teaching suggestions

\section{ABSTRACT}

Chinese is a broad and profound language, especially in terms of vocabulary, in which a word can have different meanings. Therefore, it is inevitable to cause a considerable obstacle to learners. "下" (xia) is a very specific example mentioned above. This article semantically touches on the similarities between Chinese and Vietnamese in terms of meaning and differences between the Chinese "下" and the Vietnamese "dưới" by reviewing and applying a contrasting method. As a result, a number of relevant guidance will be given for both teachers and learners via the findings. The study concludes with some appropriate teaching strategies to enhance teachers' teaching ability.

\section{Introduction}

According to the book titled 現代漢語 (tentatively translated as "Modern Chinese") written by Huang Borong, Liao Xudong states that "xia" expresses direction and position. However, if the locality word is matched with a word or a phrase of a certain word, it can still show the spatial scope, time and time meaning etc. The researcher personally encountered many students who made some mistakes in their writing and dialogue when using Chinese. Here are some examples of conversations spoken by students that the author encountered during the teaching process:

（1）他這樣地拒絕我,我也難以繼續說下 (Anh ấy cứ thế mà cự tuyệt thì thật khó mà tiếp tục nói tiếp nữa)

(2) 在這個情況中 (Trong tình huống này)

(3) 后个星期 (Tuần sau )

Example (1) lacks "Xia". In example (2), "xia" should be "zhong according to the correct semantics of the localizer. According to the correct usage in this content, in example (3) the temporality should be "xia", not "后", which means "after" in Vietnamese, literally written "sau". These kinds of ill-sentence phenomena appear in learning Chinese and can be countered in any language learning contexts. The most common reason is the interference and influence of a person's mother tongue, visually recognized in example (3) due to negative transfer. Therefore, in order to find the best teaching plan for teachers and good learning method for learners, the author intentionally points out the true nature of "Xia" through a semantic perspective, consisting of sharing the sameness with Vietnamese meaning (locality), carrying the meanings which indicate temporality and continuousness. The contrasting method used in this study not only states the distinction but also indirectly supports those concerned about the accurate wording. Eventually, the teaching steps, as a result, come into being to direct teachers for a better and more advanced education.

\section{Literature Review}

In the beginning, Huang Bo Rong and Liao Xu Dong (2002) revealed "xia" in Chinese, which indicates the direction. Later, according to Feng Sheng Li and Shi Chunhong (2017), "xia" is used as a suffix to describe the status of being under something or someone literally. In this paper, "xia" grammatically can act as various roles separately, such as subject, attributive, and object, which were recognised through examples $(3),(4),(5)$ below. "xia" semantically indicate a variety of meanings in which the corresponding

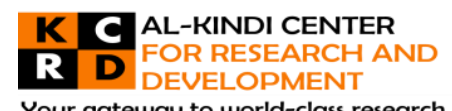

Your gateway to world-class research

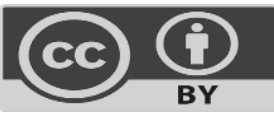

Published by Al-Kindi Center for Research and Development, United Kingdom. Copyright (c) the author(s). This open access article is distributed under a Creative Commons Attribution (CC-BY) 4.0 license 
Vietnamese meaning is really not possessing that could be seen through instances in the tables in the differences (Chinese is more temporal and continuous) given in section 4.2. Also, it is clear that in the meaning of temporality and continuousness, another appropriately corresponding word "sau" must be used in place of "dưới" in the form of the locality's meaning.

For instance:

(4) 下星期 xià xīng qī : tuần sau (next week)

(5 下个月 xià gè yuè : tháng sau ( next month)

(6) 下次 xià cì : lần sau (next time)

Examples (4),(5,(6) were realistically put into practice in a class by the author. The results we received are a wide range of learners spitting out "dưới tháng", tentatively translated as "under a month" misunderstood as lunar month. Examples (4),(5) are in the same situation as well. These cognitive biases are really normal, even frequently occurred, but it is still underestimated by the teachers believing they are not going to happen in reality. Hence, the author fiercely believes this paper will be a helpful note to make the teachers insight of matters.

\section{Methodology}

In this study, the researcher uses a reviewing method and a contrasting method to semantically investigate the word 'xi'.

\subsection{Reviewing method}

In the beginning, the author specified the study's title then reviewed the materials to evaluate whether they are related to the research. The suitable materials and the results of previous works were used for comparison.

\subsection{Contrasting method}

This method is used to analyze the mistakes due to interlanguage and help students realize the difference between Vietnamse and Chinese language indirectly and then provide some methods. Specifically, the researcher reading the found materials and taking notes of the similarities and differences related to the title, took notes of the biased sentences encountering process of teaching the Chinese "xia" for Vietnamese learners and pointed out the similarities and differences of the Chinese "xia" Vietnamese 'dưới" mainly based on semantic and grammatical perspectives.

\section{Results and Discussion}

\subsection{Common ground (both words also carry locality's meaning)}

Generally speaking, both the "xia" and "dưới" grammatical functions can act as various roles separately, such as subject, attributive, and object.

Serving as the subject：（7 上有高堂, 下有妻兒 (Trên có cha mẹ dưới có vợ con)

$$
\text { Subject Subject }
$$

There are parents at the upside and a wife and children at the downside

( means the responsibility of a man as a breadwinner )

Serving as the attributes : (8 樓 下的車是學生們的 (Chiếc xe ở dưới lầu là của các bạn học sinh)

Attributive Attributive

The car downstairs belongs to the students

Serving as objects : $\quad$ (9) 我們一定要往下看 (Chúng ta phải nhìn về phía dưới)

$$
\text { Object Object }
$$

We must look down.

From (7) (8) (9) we can see that the grammatical function of "dưới" in Vietnamese is quite similar to "xia" (下) in Chinese. Although it plays different roles, it also carries the meaning of opposition ("up" and "down").

(10) 刀過處頭落, 一腔熱血休落在地下。(Con dao rơi sước ngang đầu, máu rơi xuống đất)

The knife fell across the corner, and the blood fell on the ground.

11) 今天, 我開得很慢, 仿佛是讓自己的心情在遼闊的天空下就能夠安靜 (李開復《世界因你而不同》)

Hôm nay, tôi lái xe rất chậm, như để tâm trạng của mình tĩnh lặng dưới bầu trời bao la.

Today, I drove very slowly, as if letting my mood be quiet under the vast sky (Li Kaifu "The World is Different for You")

The word "xia"(下) can also express the meaning of space, once it is followed by the single general word (7) "地下" (underground) or the phrase (8) "天空下" (under the sky) " to form a word. When forming a sentence, locality words are sometimes combined with the preposition of "Zai"(在) just simply to emphasize the locality. 


\subsection{Differences (Chinese is more temporal and continuous)}

In Chinese, "Xia" can not only serve as a general attributive in front of a word or phrase, but it can also represent a temporal attributive; a period of time to be faced and in the future. The equivalent of "xia" and "dưới" in Chinese temporality does not exist in Vietnamese at all, while "dưới" in Vietnamese " does not have temporality. To use "sau" means " "After" to mean this.

\begin{tabular}{|l|l|}
\hline \multicolumn{1}{|c|}{ Temporal Attributive } & \multicolumn{1}{|c|}{ Corresponding in Vietnamese } \\
\hline 1. 下個禮拜你來的時候記得要帶筆記本電腦啊 ! & 1.Tuần sau bạn đến nhớ mang theo laptop nhé! \\
\hline 2. 如果下一次你來台灣, 請給我打電話。 & $\begin{array}{l}\text { 2. Lần sau bạn đến Đài Loan nhớ gọi điện thoại cho } \\
\text { tôi . }\end{array}$ \\
\hline
\end{tabular}

In addition, the Chinese "Xia" can also represent a continuous result complement. The Vietnamese "dưới" also has no continuous semantics, and "tiếp" means "continue" to express this meaning.

\begin{tabular}{|l|l|}
\hline \multicolumn{1}{|c|}{ Continuousness } & \multicolumn{1}{|c|}{ Corresponding in Vietnamese } \\
\hline $\begin{array}{l}\text { 他再三拒絕 , 真使人難以說下。 } \\
\text { He denied so many times, it is hard to us keep saying }\end{array}$ & $\begin{array}{l}\text { Anh ấy ba lần bốn lượt cự tuyệt, thật khiến người ta } \\
\text { khó mà nói tiếp ! }\end{array}$ \\
\hline $\begin{array}{l}\text { 他的歌聲就好比雷轟彈炸, 真叫人聽下不可。 } \\
\text { His voice is just like a thunder, it is so hard to make people } \\
\text { keep listening }\end{array}$ & $\begin{array}{l}\text { Tiếng hát của anh ấy cứ như tiếng sấm tiếng bom, } \\
\text { thật khiến người khác không thể nghe tiếp. }\end{array}$ \\
\hline
\end{tabular}

\section{Conclusion}

Although Vietnam is located in the Han cultural circle, Chinese foreign words are as high as $70-80 \%$, and many Vietnamese scholars believe that it is as high as $82 \%$. However, basically the language sources are different due to Chinese belonging to the SinoTibetan language family and Vietnamese to the South Asian language family. There are noticeable differences between the two langage. Therefore, whether in the teaching or translation process of "xia" in Chinese, we have to recognize them from a semantics perspective to avoid any misuses. The two words "xia" and "dưới" cannot be equated. Hence, there must be certain methods in our giving students knowledge, such as:

In the first teaching period, the most basic and most formal method is to teach learners the basic "xia" grammatical rules in teaching, including different parts of speech of different position actors to enable learners to grasp the meaning of the target language of Chinese. Locality words stand behind the nouns to indicate the location, standing in front of the nouns indicate the temporal attributive that the author mentioned above in 4.1 the common ground and 4.2 the differences, for example: "下星期 " (next week), "下次" (next time), etc., have locality, for example: "楼下" (downstairs), standing behind the verb to indicate continuously,

In the second period of teaching, when entering the deeper level, teachers should notice that learners will find out that the word "下楼" will conflict with the attributive mentioned above of standing in front of nouns to indicate temporality.

\section{(11) 下星期 (下 + 名詞 $)$ Next week（"下" + noun) Time attributive \\ (12) 下樓 (下 + 名詞) Go downstairs ( "下" + noun)}

In this circumstance, the researcher believes that stimulating the learners' thinking is to ask them to distinguish whether the noun they carry belongs to place noun or time noun. Naturally, learners will learn by themselves without a teacher.

Throughout what has been stated in this paper, the researcher believes "xia" in Chinese, despite having a variety of meanings, is still not really problematic for Vietnamese learners as long as they handle the rules with care. Specifically, when "xia" stands in front of a noun, it indicates the meaning of temporality, or it can play the role of a verb. In addition, 'xia' can be defined as the 
preposition 'under' when it is placed behind a noun. Finally, the 'xia' that follows a verb means the continuity of action. However, the researcher can only mention frequently explicit-encountered examples of how 'xia' may incorrectly be used. Hopefully, future researchers will bring more in-depth examples to highlight more possible controversies of this word to better understand Vietnamese learners' Chinese learning.

In conclusion, Chinese is a complicated and challenging subject. Whether it is from the perspective of the teacher's teaching or the perspective of the learner's absorption, we should also adopt adaptive teaching methods and practical tips that let our teaching level be improved and help learners be more absorbed and interested.

Funding: This research received no external funding.

Acknowledgements: A sincere thankfulness is sent to Dean as well as all the colleagues of the Faculty of Foreign Languages at the Ho Chi Minh City University of Food Industry for their support from the beginning of the study. All of the suggestions for the study are highly appreciated. The author, however, bears full responsibility for the paper.

Conflicts of Interest: The authors declare no conflict of interest.'

\section{References}

[1] 黃伯榮, 廖序東（2002 年）：《現代漢語》，高等教育出版社

[2] 周清海（2003 年）:《華語教學語法(Vol.6)》，玲子傳媒 LINGZI MEDIA

[3] 蘭強（2006 年）: 關於《漢越詞》, 讀書, 第 146 頁

[4] Thản, N. K. (1997). Nghiên cứu ngữ pháp tiếng Việt, NXB Giáo dục. Hà Nội (越南語)

[5] 冯胜利, 施春宏 (2017) : 《三一语法-结构、功能、语境》, 北京出版社 